\title{
Pathognomonic cerebrospinal fluid findings in Bing-Neel syndrome
}

\author{
Henrik Zetterberg
}

Received: 1 November 2010/Accepted: 20 December 2010/Published online: 9 January 2011

(C) Springer Science+Business Media, LLC. 2011

\section{To the Editor}

I read with great interest the excellent case report by Malkani et al. [1] on Bing-Neel syndrome, defined as Waldenström's macroglobulinemia (WM) with central nervous system (CNS) involvement. The clinical presentation, as well as laboratory and pathological findings, are extensively covered in the report. Nevertheless, I would like to share an illustrative gel picture showing a banding pattern of IgM in serum and cerebrospinal fluid (CSF) that should elicit suspicion regarding Bing-Neel complication of WM (Fig. 1).

Immunoblot analysis of IgM was performed on serum and CSF from a 68-year-old patient with WM and neurological symptoms according to a standard protocol [2]. In brief, serum and CSF proteins were separated by agarose gel electrophoresis using the Hydrasys 2 system (Sebia, Inc.) with Hydragel $15 \mathrm{HR}$ gels (Sebia), followed by Western blotting of proteins onto a polyvinylidene fluoride membrane, and detection of IgM using a polyclonal rabbit anti-human IgM antibody conjugated with alkaline phosphatase. The serum and CSF samples were diluted so that each lane contained a comparable amount of $\operatorname{IgM}(40 \mathrm{ng})$. The banding pattern revealed an IgM monoclonal protein in serum (Fig. 1). However, most importantly, CSF contained a much more distinct monoclonal band. IgM index, defined as [CSF-IgM (mg/l)/serum-IgM (g/l)]/[CSFalbumin $(\mathrm{mg} / \mathrm{l}) /$ serum-albumin $(\mathrm{g} / \mathrm{l})$ ], was also strongly elevated $(2.4$, normal reference range $<0.060)$. These

\section{H. Zetterberg $(\square)$}

Institute of Neuroscience and Physiology, Department of Psychiatry and Neurochemistry, The Sahlgrenska Academy at the University of Gothenburg, 43180 Molndal, Sweden e-mail: henrik.zetterberg@gu.se

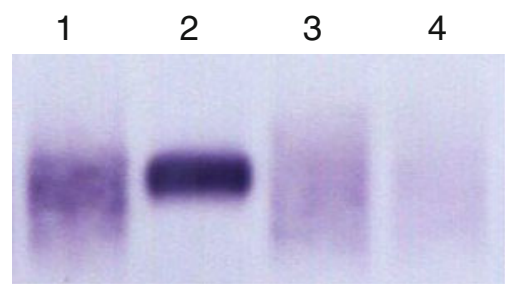

Fig. 1 Immunoblot analysis of $\operatorname{IgM}$ in serum (lane 1) and CSF (lane 2) from a patient with Bing-Neel syndrome. Lanes 3 and 4 show serum and CSF from a normal control. The results reveal a monoclonal $\operatorname{IgM}$ protein in serum (lane 1), which is enriched in CSF (lane 2)

standard laboratory investigations unequivocally show that the patient has a concentration of the IgM monoclonal protein in his CSF far above what would have been expected due to passive leakage of proteins across the blood-brain barrier. The results are explained by infiltration and proliferation of the IgM-producing malignant cell clone intrathecally, which is pathognomonic for Bing-Neel syndrome. Presence of malignant cells in CSF confirmed the diagnosis. Similar findings can be obtained for IgG and $\operatorname{IgA}$ monoclonal proteins in other types of monoclonal gammopathies with CNS involvement.

\section{References}

1. Malkani RG, Tallman M, Gottardi-Littell N, Karpus W, Marszalek L, Variakojis D, Kaden B, Walker M, Levy RM, Raizer JJ (2010) Bing-Neel syndrome: an illustrative case and a comprehensive review of the published literature. J Neurooncol 96:301-312

2. Blennow K, Skoog I, Wallin A, Wikkelso C, Fredman P (1996) Immunoglobulin $\mathrm{M}$ in cerebrospinal fluid: reference values derived from 111 healthy individuals 18-88 years of age. Eur Neurol 36:201-205 